\title{
Study of Genetic Diversity in Sunflower (Helianthus annuus L.)
}

\author{
Jay Jay Ram, U.K. Singh*, S.K. Singh and Bal Krishna
}

Department of Plant Breeding and Genetics, Tirhut College of Agriculture, Dholi, Dr. Rajendra Prasad Central Agricultural University, Pusa, Samastipur, Bihar- 848 125, India

*Corresponding author

\begin{tabular}{|l|}
\hline Ke y w o r d s \\
Genetic Diversity, \\
Sunflower, inter \\
varietal \\
hybridization \\
programme
\end{tabular}

\section{Introduction}

Sunflower (Helianthus annuus L.) emerged as an admirable crop for its quality oil in the oilseed scenario of India. The introduction of sunflower "a crop of all seasons" in India was taken up in view of its various advantages viz., photo and thermo insensitivity, short duration, high yield and better quality of oil with low cholesterol content. Sunflower belongs to family Compositeae (Asteraceae). It is diploid with chromosome number $2 \mathrm{n}=34$ and protandrous in nature wherein pollen and stigma mature at different time, therefore it has been essentially categories as a cross pollinated crop. Studies on genetic divergence are important to guide breeding programme aiming to obtain hybrid cultivars so that crosses are made among genetically divergent lines that have contrasting and complementary traits. Therefore, the breeder would choose genetically distinct parents for hybridization since heterotic crosses expected to arise as a result of crosses between divergent parental 
lines. Genetic diversity between parents of the crosses indicates differences in gene frequency, which can be exploited to improve inbreds or parental lines. The $\mathrm{D}^{2}$ analysis has been successfully utilized in sunflower to classify genotypes and determine their inter relationships by many workers (Marinkovic et al., 1992 and Teklewold et al., 2000). In this context, an attempt was made to study the genetic diversity among thirty two genotypes.

\section{Materials and Methods}

The materials used for the present investigation consisted of thirty two genotypes of sunflower (Helianthus annuus L.) including two checks which were maintained at AICRP (Sunflower) of the oil seed improvement project, Department of Plant Breeding and Genetics, Tirhut College of Agriculture, Dholi. All the thirty two genotypes have been shown in table 1 . These genotypes along with checks were sown in RBD in three replications during spring 2016 at College Farm, Tirhut College of Agriculture, Dholi. Each genotype was sown in three rows of 4.5 $m$ length with a spacing of $60 \times 30 \mathrm{~cm}$. Two to three seeds were sown per hill to facilitate better emergence and to provide uniform stand. Observations were recorded on three randomly selected plants from each row of eleven traits including days to fifty per cent flowering, plant height $(\mathrm{cm})$, days to maturity, biological yield, head diameter $(\mathrm{cm})$, harvest index, 100-seed weight $(\mathrm{g})$, volume weight $(\mathrm{g} / 100 \mathrm{ml})$, oil content $(\%)$, seed yield per plant (g) and oil yield per plant (g). Observations were recorded for yield and yield attributing characters from these tagged plants for all the genotypes in each replication except for days to fifty per cent flowering and days to maturity. The data for these two characters were recorded based on plot means. The method of recording data for each trait is described below.

\section{Days to 50 per cent flowering}

The number of days from the date of sowing to the day on which flowers in fifty per cent of the plants open were recorded.

\section{Plant height (cm)}

The height from the scar of the cotyledonary leaves to the top of the peduncle of the capitulum was measured in centimeters at the time of harvest.

\section{Days to maturity}

The number of days from the date of sowing to the day on which the back of the capitulum in fifty per cent of plants in a line turned to lemon yellow colour was recorded.

\section{Biological yield}

Total dry weight of the plant of each genotype was recorded in gram.

\section{Head diameter $(\mathrm{cm})$}

The diameter of the mature head at its maximum width was measured in centimeters.

\section{Harvest Index}

Harvesting index is the ratio of economical yield to biological yield and it was calculated by using the following formula.

Harvest index $=$

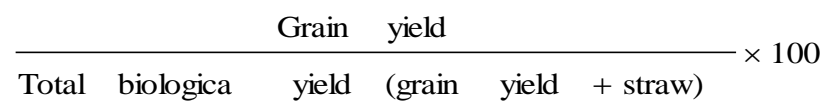

\section{0-seed weight (g)}

Total of 100 grains in each genotype was taken and weight was recorded in gram. 


\section{Volume weight $(\mathrm{g} / \mathbf{1 0 0 m l})$}

The measuring cylinder was filled to $100 \mathrm{ml}$ volume with seeds of each entry and was weighed in gram as volume weight $/ 100$ $\mathrm{ml}$.

\section{Oil content (\%)}

The seed oil content in per cent was determined directly with the help of Nuclear Magnetic Resonance (NMR) spectrometer installed at IIOR, Rajendranagar, Hyderabad.

\section{Seed yield per plant (g)}

The total weight of filled seeds per plant was recorded in grams.

\section{Oil yield per plant (g)}

Oil yield was calculated as per the formula given below

$$
\text { Oil yield }=\frac{\text { Seed yield } \mathrm{x} \text { oil content }}{100}
$$

Genetic divergence of thirty two genotypes including two checks of sunflower was assessed using the Mahalanobis $\mathrm{D}^{2}$ statistics.

\section{Results and Discussion}

Selection of suitable parents for utilization in crop improvement programme is an important but rather difficult task for plant breeders. Genetic diversity is considered to be important for realizing heterotic response in $F_{1}$ and a broad spectrum of variability in segregating generations (Arunachalam, 1981). Diversity analysis helps in assessing the nature of diversity in order to identify genetically diverse genotypes for their use in breeding programmes. In heterosis breeding programme, the diversity of parents is always emphasized more diverse the parent within a reasonable range, better the chances of improving economic characters under consideration in the resulting offspring. Mahalnobis's $\mathrm{D}^{2}$ statistic is an unique tool for classifying genetically diverse parents based on quantitative traits which could be appropriately utilized in hybridization programme.

All the genotypes were grouped into different clusters on the basis of genetic distance among the genotypes. The distribution pattern of genotypes, cluster mean for different clusters, intra and inter cluster divergence $\left(\mathrm{D}^{2}\right)$ value and contribution percentage of various traits towards genetic divergence were presented in the table 2, 3, 4 and 5 respectively.

\section{Clustering pattern}

In the present investigation, all the thirty two genotypes taken for genetic divergence analysis differed significantly with regard to the characters studied and displayed marked divergence. They were grouped into six clusters on the basis of Tocher's method of clustering utilizing $\mathrm{D}^{2}$ values. Cluster I comprised fifteen genotypes namely IB-225-1, CMS-300B-1, CMS-20B-1, IB-103, TGP-407-2, GMU-654-1, GMU-456, Morden-B-1, DRSF-108-3, GMU-681, GMU-501-1, GMU658-2, GMU-676-1, GMU-484 and IB-102-2. Cluster II comprised five genotypes namely HOLA-44, GP-6-329B-1, DRSF-108-2, R-133 and DRSF-113-1 white. Cluster III had five genotypes namely GMU-506-1, IB-101-1, Gene pool-1-6-1-2, GMU-479 and GMU-506. Cluster IV had five genotypes namely DRSF113-1, DRSF-108(C), Morden-2, Morden-1 and DRSF-113(C). Two of the thirty two genotypes namely DRSF-113-2 and LSF-711-4-1 are fall into clusters $\mathrm{V}$ and VI, respectively. Mohan and Seetharam (2005) also observed similar clustering pattern of genotypes among cluster as some cluster were unique having only single genotypes. 
Table.1 List of genotypes of Sunflower (Helianthus annuиs L.) studied

\begin{tabular}{|c|c|c|}
\hline SI. No. & Genotypes & Source \\
\hline 1 & IB- $225-1$ & IIOR, Hyderabad \\
\hline 2 & HOLA - 44 & IIOR, Hyderabad \\
\hline 3 & G.P-6- 329- B1 & IIOR, Hyderabad \\
\hline 4 & CMS -20B & IIOR, Hyderabad \\
\hline 5 & CMS-300B-2 & IIOR, Hyderabad \\
\hline 6 & GMU - 456 & IIOR, Hyderabad \\
\hline 7 & GMU - 479 & IIOR, Hyderabad \\
\hline 8 & GMU - 484 & IIOR, Hyderabad \\
\hline 9 & GMU - 501 & IIOR, Hyderabad \\
\hline 10 & GMU - 506 & IIOR, Hyderabad \\
\hline 11 & GMU- 506-1 & IIOR, Hyderabad \\
\hline 12 & GMU-654-1 & IIOR, Hyderabad \\
\hline 13 & GMU-658-2 & IIOR, Hyderabad \\
\hline 14 & GMU-676-1 & IIOR, Hyderabad \\
\hline 15 & GMU-681 & IIOR, Hyderabad \\
\hline 16 & Gene pool-1-6-1-2 & IIOR, Hyderabad \\
\hline 17 & LSF-71-1-4-1 & IIOR, Hyderabad \\
\hline 18 & DRSF-113-1 white & IIOR, Hyderabad \\
\hline 19 & $\mathrm{R}-13-3$ & IIOR, Hyderabad \\
\hline 20 & IB-101-1 & IIOR, Hyderabad \\
\hline 21 & IB-102-2 & IIOR, Hyderabad \\
\hline 22 & IB-103 & IIOR, Hyderabad \\
\hline 23 & TGP-4-07-2 & IIOR, Hyderabad \\
\hline 24 & Morden & IIOR, Hyderabad \\
\hline 25 & Morden-B-1 & IIOR, Hyderabad \\
\hline 26 & Morden-2 & IIOR, Hyderabad \\
\hline 27 & DRSF-113-1 & IIOR, Hyderabad \\
\hline 28 & DRSF-113-2 & IIOR, Hyderabad \\
\hline 29 & DRSF-108-2 & IIOR, Hyderabad \\
\hline 30 & DRSF-108-3 & IIOR, Hyderabad \\
\hline 31 & DRSF-113(C) & IIOR, Hyderabad \\
\hline 32 & DRSF-108(C) & IIOR, Hyderabad \\
\hline
\end{tabular}


Table.2 Distribution of thirty two genotypes of sunflower in different cluster

\begin{tabular}{|c|c|l|}
\hline Cluster & $\begin{array}{c}\text { No. of Genotypes } \\
\text { within cluster }\end{array}$ & \multicolumn{1}{|c|}{ Genotypes in cluster } \\
\hline I & $\mathbf{1 5}$ & $\begin{array}{l}\text { IB-225-1, CMS-300B-1, CMS-20B-1, IB-103, TGP-4-07-2, GMU- } \\
\text { 654-1, GMU-456, Morden-B-1, DRSF-108-3, GMU-681, GMU- } \\
\text { 501-1, GMU-658-2, GMU-676-1, GMU-484 and IB-102-2 }\end{array}$ \\
\hline II & $\mathbf{5}$ & $\begin{array}{l}\text { HOLA-44, GP-6-329B-1, DRSF-108-2, R-13-3 and DRSF-113-1 } \\
\text { white }\end{array}$ \\
\hline III & $\mathbf{5}$ & $\begin{array}{l}\text { GMU-506-1, IB-101-1, Gene pool-1-6-1-2, GMU-479 and GMU- } \\
506\end{array}$ \\
\hline IV & $\mathbf{5}$ & $\begin{array}{l}\text { DRSF-113-2, DRSF-108(C), Morden-2, Morden-1 and DRSF- } \\
\text { 113(C) }\end{array}$ \\
\hline $\mathbf{V}$ & $\mathbf{1}$ & DRSF-113-2 \\
\hline VI & $\mathbf{1}$ & LSF-71-1-4-1 \\
\hline
\end{tabular}

Table.3 Cluster mean for characters in sunflower

\begin{tabular}{|c|c|c|c|c|c|c|c|c|c|c|c|}
\hline & $\begin{array}{l}\text { Days to } \\
50 \% \\
\text { Flowering }\end{array}$ & $\begin{array}{c}\text { Plant } \\
\text { Height } \\
\text { cm }\end{array}$ & $\begin{array}{l}\text { Days to } \\
\text { Maturity }\end{array}$ & $\begin{array}{c}\text { Biological } \\
\text { Yield(g) }\end{array}$ & $\begin{array}{c}\text { Head } \\
\text { Diameter } \\
\text { cm }\end{array}$ & $\begin{array}{l}\text { Harvest } \\
\text { Index }\end{array}$ & $\begin{array}{c}\text { 100 Seed } \\
\text { Weight } \\
\text { gm }\end{array}$ & $\begin{array}{c}\text { Volume } \\
\text { Weight } \\
(\mathrm{g} / 100 \mathrm{ml})\end{array}$ & $\begin{array}{c}\text { Oil } \\
\text { Content } \\
(\%)\end{array}$ & $\begin{array}{c}\text { Seed } \\
\text { Yield/ } \\
\text { Plant gm }\end{array}$ & $\begin{array}{l}\text { Oil Yield } \\
\text { (g/Plant) }\end{array}$ \\
\hline Cluster I & 63.13 & 69.92 & 88.24 & 171.00 & 8.43 & 8.97 & 4.30 & 38.46 & 33.12 & 16.21 & 5.40 \\
\hline Cluster II & 58.86 & 71.11 & 85.93 & 50.53 & 7.27 & 17.00 & 3.95 & 33.36 & 29.81 & 8.60 & 2.52 \\
\hline $\begin{array}{l}\text { Cluster } \\
\text { III }\end{array}$ & 65.80 & 69.78 & 88.66 & 273.86 & 7.80 & 3.56 & 4.13 & 36.87 & 29.46 & 10.22 & 2.97 \\
\hline $\begin{array}{l}\text { Cluster } \\
\text { IV }\end{array}$ & 64.73 & 77.08 & 89.53 & 63.33 & 8.68 & 26.36 & 5.45 & 36.20 & 36.84 & 16.67 & 6.14 \\
\hline Cluster V & 70.00 & 115.93 & 95.66 & 127.66 & 15.96 & 41.20 & 7.76 & 35.43 & 32.83 & 52.63 & 17.43 \\
\hline $\begin{array}{c}\text { Cluster } \\
\text { VI }\end{array}$ & 63.00 & 71.33 & 99.66 & 237.00 & 11.43 & 3.13 & 3.83 & 47.26 & 38.13 & 7.50 & 2.83 \\
\hline
\end{tabular}

Table.4 Intra and inter cluster distances in thirty two genotypes of sunflower

\begin{tabular}{|l|c|c|c|c|c|c|}
\hline & $\begin{array}{c}\text { Cluster } \\
\text { I }\end{array}$ & $\begin{array}{c}\text { Cluster } \\
\text { II }\end{array}$ & $\begin{array}{c}\text { Cluster } \\
\text { III }\end{array}$ & $\begin{array}{c}\text { Cluster } \\
\text { IV }\end{array}$ & $\begin{array}{c}\text { Cluster } \\
\text { V }\end{array}$ & $\begin{array}{c}\text { Cluster } \\
\text { VI }\end{array}$ \\
\hline Cluster I & $\mathbf{1 3 1 . 0 7}$ & 246.87 & 247.71 & 310.91 & 347.13 & 251.26 \\
\hline Cluster II & & $\mathbf{9 3 . 0 5}$ & 417.69 & 355.65 & 442.35 & 587.31 \\
\hline Cluster III & & & $\mathbf{7 5 . 7 1}$ & 700.42 & 606.25 & 428.65 \\
\hline Cluster IV & & & & $\mathbf{1 5 3 . 6 7}$ & 364.02 & 375.84 \\
\hline Cluster V & & & & & $\mathbf{0 . 0 0}$ & 653.22 \\
\hline Cluster VI & & & & & & $\mathbf{0 . 0 0}$ \\
\hline
\end{tabular}


Table.5 Independent character contribution towards divergence in eleven characters of sunflower

\begin{tabular}{|l|c|c|}
\hline \multicolumn{1}{|c|}{ Source } & Times Ranked 1st & Contribution \% \\
\hline 1 Days to fifty per cent Flowering & 35 & 7.06 \\
\hline 2 Plant Height (cm) & 20 & 4.03 \\
\hline 3 Days to Maturity & 0 & 0.00 \\
\hline $\mathbf{4}$ Biological Yield (g) & 197 & 39.72 \\
\hline $\mathbf{5}$ Head Diameter (cm) & 3 & 0.60 \\
\hline 6 Harvest Index (\%) & 8 & 1.61 \\
\hline $\mathbf{7}$ 100 Seed Weight $(\mathbf{g})$ & 4 & 0.81 \\
\hline $\mathbf{8}$ Volume Weight (g/100ml) & 1 & 0.20 \\
\hline 9 Oil Content (\%) & 178 & 35.89 \\
\hline 10 Oil Yield (g/Plant) & 1 & 0.20 \\
\hline 11 Seed Yield (g/plant) & 49 & 9.88 \\
\hline
\end{tabular}

Genotypes grouped into the same cluster presumably diverge little from one another as the aggregate of characters measured. Theoretically crossing of genotypes belonging to the same cluster is not expected to yield superior hybrid or segregant. In general, larger the divergence between the genotypes, the higher will be the heterosis.

\section{Cluster means for different characters}

A comparison of the mean values of eleven traits for different clusters showed considerable differences among them. Cluster VI comprising genotype LSF-71-1-4-1 had the maximum mean value for days to maturity (99.66), volume weight (47.26) and oil content (38.13) whereas minimum mean values for harvest index (3.13), 100 seed weight (3.83), seed yield per plant (7.50) and days to fifty per cent flowering (63.00). Cluster V comprising genotype DRSF-113-2 had the maximum mean value for plant height (115.93), days to fifty per cent flowering
(70.00), seed yield per plant in gram(52.63), harvest index(41.20), oil yield (17.43), head diameter (15.96) and 100 seed weight (7.76).

Cluster III had maximum mean value for biological yield (273.86) and minimum mean value for plant height (69.78) and oil content (29.46). Cluster II had minimum mean value for days to maturity (85.93), biological yield (50.53), volume weight (33.36), head diameter (7.27) and oil yield (2.5).

III. Average intra and inter cluster distances $\left(D^{2}\right)$

Maximum intra cluster distance was observed in cluster IV followed by cluster I and cluster II indicating differences in genotypes within cluster. Least intra cluster distance was found in cluster III indicating that close resemblance between the genotypes present in the cluster. The genotypes in cluster III and cluster IV, due to maximum inter cluster distance between them, exhibited high degree of 
genetic diversity and thus may be utilized under inter varietal hybridization programme (transgressive breeding) for getting high yielding recombinants. Similar inter varietal crosses may be attempted in cluster $\mathrm{V}$ and cluster VI and cluster III and cluster V for getting high recombinants. The lowest inter cluster distance was observed between cluster I and II followed by between cluster I and III and cluster I and VI showing this cluster was relatively less divergent and crossing between them cannot produce vigorous offspring $\left(\mathrm{F}_{1}\right.$ progenies). Similar studied based on $\mathrm{D}^{2}$ statistics was also performed by that of Shamshad et al, (2014) and Neelima et al, (2016).

\section{Contribution percentage of each character towards divergence}

The highest contribution in the manifestation of total genetic divergence was exhibited by biological yield (39.72) followed by oil content (35.89), seed yield (9.88), days to fifty per cent flowering (7.06), plant height (4.03) and head diameter (1.61). The contribution of remaining traits in manifestation of genetic divergence was low.

\section{References}

Arunachalam, V., 1981, Genetic distance in plant breeding. Indian Journal Genetics. 41: $226-236$.

Mahalanobis, P. C., 1936, On the generalized distance in statistics. Proceedings of National institutes of sciences, India, 2: 49-55.

Marnikovic, R. 1992. Path coeicient analysis of some yield components of sunlower. Euphytica. 60: 201-205.

Mohan, G. S. and Seetharam, A., 2005, Genetic divergence in lines of sunflower derived from interspecific hybridization. Sabrao Journal. 37: 77-84.

Neelima, S K., Kumar, A. K., Venkataramanamma and Padmalatha, Y. 2016. Genetic variability and genetic diversity in sunflower. Electronic Journal of Plant Breeding, 7(3): 703707.

Shamshad, M., S.K. Dhillon, S. K., Tyagi, V. and Akhatar, J. 2014. Assessment of Genetic Diversity in Sunflower (Helianthus annuus L.) Germplasm. International Journal of Agriculture and Food Science Technology. 4 (2014), pp. 267-272.

Teklewold, A., Jayaramaiah, H. and Jayaramegowda, 2000, Genetic divergence studie in sunflower (Helianthus annuus L.). Helia, 23: 93104.

\section{How to cite this article:}

Jay Jay Ram, U.K. Singh, S.K. Singh and Bal Krishna. 2018. Study of Genetic Diversity in Sunflower (Helianthus annuus L.). Int.J.Curr.Microbiol.App.Sci. 7(05): 2266-2272.

doi: https://doi.org/10.20546/ijcmas.2018.705.263 